\title{
POTASSIUM DIFORMATE : A NEW ALTERNATIVE TO ANTIBIOTIC GROWTH PROMOTERS
}

\author{
R. Chowdhury, M. N. Haque, K. M. S. Islam and M. J. Khan ${ }^{1}$
}

\begin{abstract}
Potassium diformate (Formi) is odorless, low-corrosive and easy to handle. The European Union (EU) has approved it as non-antibiotic growth promoter, for use in non ruminant feeds. Maximum inclusion level of potassium diformate is $1.8 \%$ as registered by the European authorities which can improve weight gain up to $14 \%$. Potassium diformate contains the active ingredients free formic acid as well as formate has the strong anti microbial effect in stomach and also in duodenum. Potassium diformate with its growth promoting and health enhancing effect has proven to be an alternative to antibiotic growth promoters. Its special effect on the micro flora is regarded as the main mode of action. $1.8 \%$ potassium diformate in growing pig diets also significantly increase Feed intake and feed conversion ratio was significantly improved where growing pig diets was supplemented with $1.8 \%$ potassium diformate. It was also reduced $\mathrm{pH}$ in the stomach and duodenum. potassium diformate $0.9 \%$ significantly reduced the $\mathrm{pH}$ of duodenal digesta.
\end{abstract}

Key words : Potassium diformate, Growth promoter, Animal

\section{Background}

Antibiotic growth promoters have been widely used in animal feed, with considerable success. Antimicrobial feed additives are widely used to improve the performance and ecology of animal production (Gropp et al., 1992). Ban on antibiotics as growth promoters in the European Union, and the resulting pressures on meat exporters around the world have increased interest on alternatives like herbs, herbal products, prebiotics, probiotics organic acids (formic, fumaric, citric, lactic, propionic etc.). Organic acids and their salts have received much attention as alternatives to antibiotic growth promoters. These vary in the growth promoting effect and mode of action. Also, physical properties such as ease of handling, odor and corrosion during feed processing and on the farm should be taken into account when evaluating the different formulations. Numerous studies have demonstrated that formic acid is effective against pathogenic bacteria and enhancing growth performance but strong odor and corrosiveness limit its use (Øverland et al., 1999).

To overcome these problems, Potassium Diformate (PD) has received attention as an alternative to formic acid because of its easiness to handle and also effective in enhancing

Corresponding author : Department of Animal Nutrition, Bangladesh Agricultural University, Mymensingh-2202, Bangladesh

(Received : December 31, 2008) 
Bang. J. Anim. Sci. 2008, 37(2)

growth performance (Øverland et al., 1999). Formi is the brand name of non-antibiotic growth promoter potassium diformate which was invented by BASF Fine Chemical's Animal Nutrition. It contains $98 \%$ PD, $1.5 \%$ silicates and $0.5 \%$ water. It is not only the first EU-approved alternative to feed antibiotics for pigs, but also the first import product approved by China. The product has been widely used in Europe and Asia.

\section{Physical and chemical properties of potassium diformate (PD)}

\begin{tabular}{|ll|}
\hline Structure & II \\
& \\
Molecular formula & $\mathrm{C}_{2} \mathrm{H}_{3} \mathrm{KO}_{4}$ \\
Typical Content & Potassium Diformate $\geq 97 \%$ \\
Loss on drying & $\leq 3 \%$ \\
Appearance & White crystalline or slightly yellowish granular \\
Molecular weight & 136.16 \\
Solubility & Easily soluble in the water. \\
\hline
\end{tabular}

Source : Kjeldsen and Øverland, 2003.

\section{Efficacy}

The product brings about an acidic state within intestines of pigs, which helps to raise the assimilating enzymatic activity, then it can improve the taste of feedstuff, and increase feed intake, daily gain and feed efficiency of piglet and growing pig, and can also increase milk yield. The product can reduce Escherichia coli and Salmonella, increase beneficial bacteria, and decrease diarrhea occurrence rate through making the $\mathrm{pH}$ of intestines lower. It can also improve pig's utilization ratio to nitrogen and phosphorus, and prevent piglet's edema. The product can be used safely with a high efficacy having no toxicity, and residual characteristic. It does not make any harm to man, animal and environment.

\section{Recommended dosage for pigs}

\begin{tabular}{|l|c|}
\hline \multicolumn{1}{|c|}{ Species } & Dosages (\%) \\
\hline Sucking Pig & $0.6-1.4$ \\
Weaned Piglet & $0.6-1.2$ \\
Growing Pig & $0.6-1.0$ \\
Finishing Pig & 0.6 \\
Pregnant Sow & 0.6 \\
Lactating Sow & 0.6 \\
\hline
\end{tabular}




\section{Mode of action}

The primary mode of action is via an antimicrobial effect of formic acid and formate resulting from the dissociation of $\mathrm{PD}$ in the gastrointestinal tract. It is mainly the undissociated form of the formic acid that exerts the antimicrobial effect (Ostling and Lindgren, 1993). The concentration of the undissociated acid increases with decreasing the $\mathrm{pH}$. Formic acid passively diffuses through the bacteria cell wall, interfering with the finetuned $\mathrm{pH}$ balance in the cytoplasm, which results in a fatal interruption of the energy balance and biochemical processes. There is also a suppression of the cells' enzymes and nutrient transport systems, which inhibits the ability of the bacteria to multiply (Partanen and Mroz, 1999; Roth and Kirchgessner, 1998).

\section{Potassium diformate in animal diet}

The European Community has registered Potassium Diformate (PD) as the first nonantibiotic animal nutrition product with growth-promoting properties under EC 1334/2001.The antimicrobial effect of PD reduces the general bacterial population in the gut especially harmful bacteria such as E. coli and Salmonella and promotes a more favorable microflora in the gut. This improves the animal's growth performance and health status, while at the same time ensuring safer products for the consumer.

\section{Effect of potassium diformate on growth, feed intake and feed conversion}

Comprehensive studies have shown that performance of growing, pig and broiler can be improved significantly by the use of organic acid. As a consequence industrial feed additives have been developed containing only one organic acid or their salts. One of the latest developments is the Potassium diformate. It contains $36.4 \%$ of formic acid, $34.6 \%$ formate and $30 \%$ potassium. Paulicks et al. (1996) conducted a dose titration trial to evaluate the effect of increasing inclusion level of PD on performance of growing piglets. Potassium diformate was added at $0,0.4,0.8,1.2,1.6,2.0,2.4$ and $2.8 \%$ level to piglet starter cornsoybean based diet. Potassium diformate improved daily weight $13 \%$, daily feed intake $9 \%$ and feed conversion ratio $4 \%$ on average supplemented groups. Weight gain improved $22 \%$ compared to the untreated group with an addition of $2 \% \mathrm{PD}$. With a maximum inclusion level of $1.8 \%$ as registered by the European authorities weight gain can be improved up to $14 \%$. Feed intake was significantly improved in same dose. Feed conversion ratio (FCR) improved linearly from 1.59 to 1.47 with an increasing level of PD. Several researchers investigated the effect of PD on performance of piglet. Table 1 gives a summary of some experiments on the effect of PD on weight gain (WG) and FCR.

Potassium diformate is registered as a non antibiotic growth promoter with the purpose to replace in feed antibiotics ensuring safer products to the consumers. Therefore the benefits of using potassium diformate have to be compared to effect achieved with the conventional use of feed antibiotics. One of the commonly used feed antibiotics in pig is tylosin. Danielsen (1998) compared performance of pigs treated with the antibiotic growth promoter tylosin or with PD. The experiment involved a control group, three treatments with increasing levels of 
Bang. J. Anim. Sci. 2008, 37(2)

PD $(0.6 \%, 1.2 \%$, and $1.8 \%)$, one treatment with a supplementation of $40 \mathrm{ppm}$ tylosin and one treatment with a combination of $1.2 \% \mathrm{PD}$ and $150 \mathrm{ppm} \mathrm{Cu}$. Weight gain increased $40 \%$ in application of $1.8 \%$ PD and $40 \mathrm{ppm}$ of tylosin. Feed intake and FCR also improved in 1.8 $\%$ PD treated group. The result clearly demonstrated that, PD can replace a feed antibiotic without any negative impact on animal performance. It has been demonstrated that PD significantly improves animal performance to an extent comparable to commonly used antibiotics. The performance effects of PD are mainly due to its antimicrobial properties.

Table 1. Effect of potassium diformate on weight gain and feed conversion ratio in animal

\begin{tabular}{|l|c|c|l|}
\hline PD (\%) & WG (relative \%) & FCR (relative \%) & \multicolumn{1}{c|}{ References } \\
\hline 0.0 & 100 & 100 & \\
0.5 & 107 & 98 & Roth et al, 1996 \\
1.0 & 110 & 96 & Paulicks et al,. 1996 \\
1.5 & 113 & 94 & Kirchgessner et al,. 1997 \\
2.0 & 117 & 91 & Roth, 1999 \\
2.5 & 122 & 89 & Danielsen, 1998 \\
\hline
\end{tabular}

\section{Antimicrobial effect of potassium diformate}

Although organic acid generally lower the $\mathrm{pH}$ value in the stomach and parts of the upper gastro intestinal tract and therefore enhance proteolytic activities, a major effect of PD lies in the alteration of the microbial flora within the gut. Evidence exists that, PD significantly reduce the total number of coliform bacteria in the duodenum, jejunum and rectum in host animal. The antimicrobial effect of PD in the gut is expressed in three ways:

There is a general reduction of the microbial number in the small intestine. As the microbial population is reduced, fewer nutrients are consumed by the micro flora. Here is also less microbial metabolites (e.g. ammonia) increase gut mucosa turnover. This increases the availability of dietary energy and nutrients to the host animal and reduces maintenance cost of the gut, resulting in increased growth rate and enhanced feed efficiency. Thus, the improvement in nutrient digestibility is probably associated with the change in the micro flora in the gut. High concentration of ammonia in the gut has a negative effect on growth rate of pigs. Several researchers reported that, addition of PD in diet decrease the ammonia concentration in gut (Hebeler et al., 2000 and Fevrier et al., 1999). Table 2 represents the summarization of several research findings on antimicrobial effect of PD.

This reduces the E. coli, Salmonella and overall exposure of the animal by these pathogenic bacteria as well as the toxins produced. The antimicrobial effect of PD is stronger against potential pathogens e.g. Coliform bacteria than towards the desirable bacteria such as lactic acid bacteria. This leads to a shift in the composition of microbes to a more balanced micro flora in the gut, which also improves the general health status of the animals. Results from in 
vitro trials using $0.6 \%$ PD (Knarreborg et al., 2000) and $1.8 \%$ PD (Fevrier et al., 1999) shows that, PD reduced the population of both Coliform bacteria and Lactobacilli in vitro and in the stomach of piglets. The antimicrobial effect was stronger towards Coliform bacteria than towards Lactobacilli, resulting in an increased ratio between lactic acid bacteria and coliform bacteria in vitro and in the piglets.

Table 2. Reduction of microbial load in the gastrointestinal tract of pig

\begin{tabular}{|c|c|c|c|c|c|c|c|}
\hline \multirow{2}{*}{ PD (\%) } & \multicolumn{6}{|c|}{ Total Coliform bacteria in finishing pig (No of bacteria $\log / \mathrm{CFU} / \mathrm{g}$ ) } & \multirow{2}{*}{ References } \\
\hline & \multicolumn{2}{|c|}{ Duodenum } & \multicolumn{2}{|c|}{ Jejunum } & \multicolumn{2}{|c|}{ Rectum } & \\
\hline 0 & \multicolumn{2}{|c|}{3.8} & $\begin{array}{c}\text { Jejunum } \\
4\end{array}$ & \multicolumn{3}{|r|}{5} & \multirow{2}{*}{$\begin{array}{l}\text { Overland et al., } \\
2000\end{array}$} \\
\hline 1.2 & \multicolumn{2}{|l|}{2.5} & 2.8 & \multicolumn{3}{|r|}{4} & \\
\hline \multirow[b]{2}{*}{ PD (\%) } & \multicolumn{6}{|c|}{ Growing finishing pig (No of bacteria log/CFU/g) } & \\
\hline & Lactobacilli & E. coli & Tot. aerobe & \multicolumn{2}{|c|}{$\begin{array}{c}\text { Tot. } \\
\text { anaerobe }\end{array}$} & Enterococci & \\
\hline 0 & 8.5 & 7.2 & 8.4 & & 9.8 & 7.4 & \multirow{2}{*}{$\begin{array}{l}\text { Hebeler et al., } \\
2000\end{array}$} \\
\hline 1.8 & 7.5 & 6 & 7.8 & & 7.9 & 6.8 & \\
\hline \multirow{2}{*}{ PD (\%) } & \multicolumn{6}{|c|}{ Growing Finishing pig(log CFU/g) } & \\
\hline & \multicolumn{2}{|c|}{ Yeast in stomach } & \multicolumn{2}{|c|}{ Coliform in stomach } & \multicolumn{2}{|c|}{ Coliform in ceacum } & \multirow{3}{*}{$\begin{array}{c}\text { Overland et al., } \\
2000\end{array}$} \\
\hline 0 & \multicolumn{2}{|l|}{4.7} & \multicolumn{2}{|c|}{4} & \multirow{2}{*}{\multicolumn{2}{|c|}{$\begin{array}{l}6.5 \\
5.7\end{array}$}} & \\
\hline 1.0 & \multicolumn{2}{|l|}{3.5} & \multicolumn{2}{|l|}{3.2} & & & \\
\hline
\end{tabular}

$\mathrm{PD}=$ Potassium diformate

\section{Antimicrobial effect of potassium diformate in animal feed}

Increased feed intake has been observed in several trials when PD has been added in the diets. This may be associated with a better quality and improved biosecurity of the feed or an improved health status of the animals. Salts of organic acids are often considered to be nearly inert in the feed. Granli et al. (2002) reported that, addition of $1.8 \%$ PD significantly reduced the quantity of salmonella in contaminated feed. PD has a similar antimicrobial effect towards other types of bacteria, such as $E$. coli. The animal is therefore exposed to fewer in-feed pathogenic bacteria and there may be fewer toxic metabolites and hence reduced spoilage. The quality and palatability of the feed is improved when PD is included in the diets. As a consequence, feed intake and growth rate is increased. The antimicrobial effect of PD is considered to be the main mode of action. The strong antimicrobial effect in the gut results from a high concentration of both formic acid and lactic acid in stomach and duodenum as well as a reduction of $\mathrm{pH}$.

\section{The pH lowering effect of potassium diformate}

The performance enhancing effects of organic acids and their salts extensively described in the literature. As reasons for these effects, the influence of organic acids on the feed, on the intestine and on the intermediate metabolism are discussed but are mainly the two latter aspects seems to be more relevant. As piglets immediately after weaning have an inadequate 
Bang. J. Anim. Sci. 2008, 37(2)

$\mathrm{HCl}$ production in the stomach, the addition of organic acids helps to support the physiological digestive functions by decreasing the $\mathrm{pH}$ value in the stomach. PD contains an active ingredient free formic acid as well as formate. The strong anti microbial effect of PD can be explained by the high concentration of active ingredient present not only in stomach but also in duodenum (Daza et al., 2001). A more rapid reduction in the $\mathrm{pH}$ of the stomach stimulates the secretion of pepsin and pepsinogen, which may enhance dietary protein digestion. A reduced $\mathrm{pH}$ in the lumen also contributes to the antimicrobial effect of the additive. Lower $\mathrm{pH}$ conditions have a direct inhibitory effect on the bacteria population in the lumen (Mroz et al, 2000).

\section{Effect of potassium diformate on nutrient utilization}

Performance effects of organic acids are not only related to their effects on unfavorable microorganism and also the effect to lower the $\mathrm{pH}$ value in the gastro intestinal tract. Furthermore, the anion of the acid has a positive influence on the eubiosis among the intestinal micro- flora. All these effects relieve the intermediate metabolism and contribute to a higher performance. An improved nutrient utilization is partly a result of a decreased competition from microorganism for nutrients but is also a result of a more efficient enzymatic digestion of nutrients. Roth et al. (1998) reported that, application of 1.8\% PD increased digestibility reflects primarily changes in the activity of the hindgut micro-flora. Since about $80 \%$ of the fecal nitrogen is of microbial origin the result obtained in their study indicate that the supplementation of PD reduce the amounts of fermentable nutrients entering the hindgut by improving the enzymatic digestion in the small intestine. They also suggesting that it may improve carcass leaness by making amino acids more available for protein deposition within the body. Partanene and Mroz (1999) stated that, the improvement in protein digestibility is expected to be greater with a protein source of a lower quality than a higher quality.

\section{Conclusion}

Potassium diformate improves animal performance in terms of weight gain, feed intake and feed conversion. The improvements in performance are equal to growth promoters. Therefore potassium diformate with its performance and health enhancing properties is an effective alternative to feed antibiotics. Effect on the microflora is regarded as the main mode of action and no risk of developing resistance in microorganisms. It reduces the incidence of E. coli and Salmonella in meat products and therefore contributes to food safety.

\section{Literature Cited}

Danielsen, V. 1998. Nutriciony Almentacion de lechones en condiciones de manejo del morte de Europea. XIV Curso de especializacion avances en nutricion y alimentacion animal, Spain.

Daza, A., Ovejero, I. and Flox, J. R. 2001. Effect of potassium diformate on performance and health status of weaning piglets. Anaporc Cientifico, 1(1) : 15-25. 
Février C., Gotterbarm, G. G., Jaguelin-Peyraud, Y. Y., Lebreton, Legouevec, F. and Aumaitre, A., 1999. Effects of the addition of potassium diformate and phytase in the starter diet of the weaned piglet. 8th Symposium on Digestive Physiology in Pigs. Uppsala Sweden.

Granli, T., Øverland, M., Kjeldsen, K. C. and Mroz, Z. 2002. Antimicrobial properties of dietary potassium diformate in pigs. 3rd Joint Symposium RRI-INRA: Beyond antimicrobials future of gut microbiology. Aberdeen.

Gropp J. M., Birzer D. and Schuhmacher A. 1992. Vom Gesamtnutzen der Futterzusatz-stoffe; ein Beitrag zur Auflösung des Widerstreits von Ökonomie und Ökologie. pp. 168-204.

Hebeler, D., Kulla, S., Winkenwerder, F., Kamphues, J., Zentek, J. and Amtsberg, G. 2000. Influence of a formic acid potassium formate- complex on chyme composition as well as on the intestinal microflora of weaned piglets. Hanover $54^{\text {th }}$ Proceedings. Society of Nutritional Physiology, Göttingen, Germany.

Kirchgessner, M., Paulicks, B. R. and Roth, F. X. 1997. Effects of supplementation of diformate complexes (Form LHS) on growth and carcass performance of piglets and fattening pigs. Agribiological research, 50(1) : 1-10.

Kjeldsen, K., and Øverland, M. 2003. Formi ${ }^{\circledR}-$ The first approved alternative to feed antibiotics. KRMIVA, $10^{\text {th }}$ International conference, Opatija, Kroatia.

Knarreborg, A., Miquel, N., Granli, T. and Jensen, B. B. 2000. In vitro methodology to evaluate the effect of various additives on the microflora in gastrointestinal tract of pigs. Digestive Physiology in Pigs: Proceedings of the 8th symposium, pp. 302-304.

Mroz, Z., Jongbloed, A.W., Van der Weij-Jongbloed, R. and Øverland, M. 2000. Postprandial flow rates of formic acid and potassium in duodenal digesta of weaned piglets fed graded doses of potassium diformate. 8th Symposium on Digestive Physiology in Pigs. Uppsala Sweden.

O“stling, C. E., and Lindgren, S. E. 1993. Inhibition of enterobacteria and Listeria growth by Lactic, acetic and formic acids. Journal of Applied Bacteriology, 75 : 18-22.

Øverland, M., Steien, S. H., Gotterbarm, G. and Granli, T. 1999. Formi LHS- An alternative to antibiotic growth promoters. $50^{\text {th }}$ annual EAAP meeting, Zurich, Switzerland.

Øverland, M., Granli, T., Kjos, N. P., Fjetland, O., Stokstad, M. and Steien, S. H. 2000. Effect of dietary formates on growth performance, carcass traits, sensory quality, intestinal microflora, and stomach alterations in growing-finishing pigs. Journal of Animal Science, 78 : 1875-1884.

Partanen, K., and Mroz, Z. 1999. Organic acids as an alternative for prophylactic medication of pig diets. Nutr. Res. Rev. $12: 1-30$.

Paulicks, B. R., Roth, F. X. and Kirchgessner, M. 1996. Does effects of potassium diformate (Formi LHS) on the performance of growing rabbit. Agribiological research. 49(4) : 318-326.

Roth, F. X. 1999. Experimental report on the dose response effects of Formal LHS in post weaning piglets. Internal report.

Roth, F. X. and Kirchgessner, M. 1998. Organic acids as feed additives for young pigs: Nutritional and gastrointestinal effects. Proceedings Journal of Animal and Feed Sciences, 7(1): 25-33.

Roth, F. X., Kirchgessner, M. and Paulicks, B. R. 1996. Nutritive use of feed additives based on diformates in the rearing and fattening of pigs and their effects on performance. Agribiological Research, 49(4) : 307-317.

Roth, F. X., Windisch, W. and Kirchgessner, M. 1998. Effect of potassium diformate (Forml LHS) on nitrogen and nutrient digestibility in piglets at graded dietary lysine levels. Agribiological research, 51(2) : 1-8. 